\title{
Long-term (trophic) purinergic signalling: purinoceptors control cell proliferation, differentiation and death
}

\author{
G Burnstock ${ }^{*, 1}$ and A Verkhratsky ${ }^{2,3}$
}

The purinergic signalling system, which uses purines and pyrimidines as chemical transmitters, and purinoceptors as effectors, is deeply rooted in evolution and development and is a pivotal factor in cell communication. The ATP and its derivatives function as a 'danger signal' in the most primitive forms of life. Purinoceptors are extraordinarily widely distributed in all cell types and tissues and they are involved in the regulation of an even more extraordinary number of biological processes. In addition to fast purinergic signalling in neurotransmission, neuromodulation and secretion, there is long-term (trophic) purinergic signalling involving cell proliferation, differentiation, motility and death in the development and regeneration of most systems of the body. In this article, we focus on the latter in the immune/defence system, in stratified epithelia in visceral organs and skin, embryological development, bone formation and resorption, as well as in cancer.

Cell Death and Disease (2010) 1, e9; doi:10.1038/cddis.2009.11; published online 14 January 2010

Subject Category: Experimental Medicine

This is an open-access article distributed under the terms of the Creative Commons Attribution License, which permits distribution and reproduction in any medium, provided the original author and source are credited. This license does not permit commercial exploitation without specific permission.

\section{ATP - The Universal Intercellular Signalling Molecule}

The molecule of adenosine 5'-triphosphate or ATP was discovered 80 years ago simultaneously in Heidelberg and Boston by Lohman, ${ }^{1}$ Fiske and SubbaRow. ${ }^{2}$ Very soon afterwards, the central role of ATP in cell energetics was fully appreciated. ${ }^{3}$ In fact, the role of ATP in living matter is unique and without ATP we, in all probability, would not witness life in its present forms.

Indeed, the life forms, which we know on earth, are built around the genetic code that is stored in the relatively simple molecules of DNA and RNA, composed from the purine adenine and the pyrimidines, guanine, uracil and thymine. The purines and pyrimidines, as well as ATP and GTP, most likely appeared in the prebiotic period, with adenine derivatives being preferentially synthesised as a result of purely thermal reactions. ${ }^{4,5}$ Very early in evolution, ATP was chosen as an energy substrate, thus shaping the metabolism of all forms of life. ${ }^{6}$ The preponderance of ATP stimulated the evolution of enzymes with preferential binding properties, and adenine nucleotides began to be used in various intracellular signalling cascades, such as, for example, the cAMP cascade. ${ }^{7}$ At the very same time, ATP probably became the first extracellular signalling molecule, because of its sheer availability. Indeed, as every cell contained high concentrations of ATP, cell damage inevitably results in the appearance of ATP gradients in the surrounding milieu, which thus became a universal 'danger' signal. As a result, virtually every known cell or singlecell organism has a form of ATP sensitivity, and purinergic signalling represents the primordial form of chemical intercellular signalling. ${ }^{8}$

Although the intracellular signalling and metabolic roles for ATP were established quite early, its importance as an extracellular signalling molecule was acknowledged much later. The possible signalling role for AMP was postulated in $1929^{9}$ and purinergic signalling (i.e., signalling mediated by purines and pyrimidines) was initially suggested in 1970, when ATP was identified as a transmitter in the autonomic nervous system. ${ }^{10}$ In 1972 , the concept of purinergic nerves and purinergic transmission was formulated, ${ }^{11}$ and after initial

\footnotetext{
${ }^{1}$ Autonomic Neuroscience Centre, Royal Free and University College Medical School, London NW3 2PF, UK; ${ }^{2}$ Faculty of Life Sciences, The University of Manchester, Manchester M13 9PT, UK and ${ }^{3}$ Institute of Experimental Medicine, ASCR, Prague, Czech Republic

${ }^{*}$ Corresponding author: G Burnstock, Autonomic Neuroscience Centre, Royal Free and University College Medical School, Rowland Hill Street, London NW3 2PF, UK. Tel: + 44207830 2948; Fax: + 44207830 2949; E-mail: g.burnstock@ucl.ac.uk

Keywords: ATP; P2X and P2Y receptors; epithelia; immune cells; bone; cancer

Abbreviations: ADP, adenosine diphosphate; AMP, adenosine monophosphate; ATP, adenosine 5'-triphosphate; ATP $\gamma \mathrm{S}$, adenosine 5'-0-(3-thiotriphosphate); BzATP, 2'-\&3'-O-(4-benzoyl-benzoyl)-ATP; DNA, deoxyribose nucleic acid; cAMP, cyclic adenosine monophosphate; GTP, guanosine triphosphate; IL, interleukin; InsP3, inosine trisphosphate; LTP, long-term potentiation; 2-MeSADP, 2-methylthio ADP; NGF, nerve growth factor; NO, nitrous oxide; TNF- $\alpha$, tumour necrosis factor- $\alpha$; UTP, uridine 5'-triphosphate

Received 04.11.09; accepted 09.11.09; Edited by M Piacentini
} 
resistance is now widely accepted and has a major role in both the nervous system ${ }^{12-14}$ and non-neuronal cells. ${ }^{15}$ Initially, the focus was on short-term purinergic signalling in neurotransmission, neuromodulation and secretion, but more recent studies have also established roles in long-term (trophic) signalling in cell proliferation, differentiation, motility and death in development and regeneration. ${ }^{16,17}$

\section{The Omnipresent Purinoceptors}

The action of purines and pyrimidines is mediated through an extended family of purinoceptors, ${ }^{18,19}$ generally divided into $\mathrm{P} 1$ adenosine receptors ${ }^{20}$ and $\mathrm{P} 2$ receptors for ATP and related nucleotides. ${ }^{21,22}$ In the early 1990s, receptors for purines and pyrimidines were cloned and characterised $^{12,23-25}$ and it is currently recognised that there are four subtypes of $P 1$ receptors $\left(A_{1}, A_{2 A}, A_{2 B}\right.$ and $\left.A_{3}\right)$, seven subtypes of $P 2 X$ ligand-gated ion channel receptors $\left(P 2 X_{1-7}\right)$ and eight subtypes of P2Y G-protein-coupled receptors $\mathrm{P}_{2 Y_{1}}, \mathrm{P}_{2} \mathrm{Y}_{2}, \mathrm{P}_{2} \mathrm{Y}_{4}, \mathrm{P} 2 \mathrm{Y}_{6}, \mathrm{P}_{2} \mathrm{Y}_{11}, \mathrm{P} 2 \mathrm{Y}_{12}, \mathrm{P} 2 \mathrm{Y}_{13}$ and $\left.P 2 Y_{14}{ }^{26}\right)$. P2 receptors appeared very early in evolution, for example, P2X receptors have been found in early prokaryotes; ${ }^{27-29}$ despite little sequence homology with later evolutionary forms of the receptors, the functional properties are very much conserved. Similarly, functional metabotropic (P2Y-like) receptors are present in Protozoa, and in the most primitive plants in which they regulate numerous vital functions. ${ }^{8,30}$

The $\mathrm{P} 1$ and $\mathrm{P} 2 \mathrm{Y}$ receptors are classical 7-transmembrane domain receptors, the action of which is mediated through G-proteins and numerous intracellular second messengers, including the cAMP and InsP $\mathrm{P}_{3}$ cascades. In addition, some of these receptors are linked to membrane ion channels, thus mediating plasmalemmal ion fluxes and electrophysiological effects. P2X receptors are archetypal ligand-operated cationic channels, ${ }^{31-33}$ many of which have an appreciable $\mathrm{Ca}^{2+}$ permeability. ${ }^{34}$ The P2X channels are assembled (in a homoor heteromeric manner) from seven subunits, designated as $\mathrm{P}_{2} \mathrm{X}_{1}-\mathrm{P} 2 \mathrm{X}_{7}$, which determines the variability of their biophysical and pharmacological properties.

Probably because of their ancient origin, the extensive array of purinoceptors has a unique property of being extraordinarily widely distributed throughout living cells and tissues (Table 1). In contrast to all other chemical transmitters, which are, as a rule, segregated to certain cell types and certain functions, the receptors for purines and pyrimidines are found everywhere and as a matter of fact it is almost impossible to find a cell without sensitivity to ATP and its analogues. Indeed, purinoceptors are extensively present in the central nervous system, where they mediate fast synaptic transmission, provide for presynaptic inhibition and regulation of neuronal excitability and are particularly important for signalling in neuronal-glial circuitry, being one of the most important gliotransmitters. ${ }^{12,13,35,36}$ In the peripheral nervous system, purinoceptors are involved in sensory ${ }^{37,38}$ and autonomic functions. ${ }^{39}$ Purinoceptors are present in all peripheral tissues, being involved in the regulation of very different functions in the gut, kidneys, in the cardiovascular and respiratory systems, the immunological system, in blood cells, skin, bones and muscles. ${ }^{8,15}$ Furthermore, the purinergic signalling system possesses another unique property - the release of the principal mediator, ATP, initiates the appearance of a trail of derivatives, ADP, AMP and adenosine, to which extracellular ATP rapidly degrades due to the activity of ectonucleotidases that represent an important component of purinergic signalling. ${ }^{13}$ As a result of the single event of ATP release from different cell types (which occurs through different concomitant mechanisms, including $\mathrm{Ca}^{2+}$-regulated exocytosis, membrane transporters and diffusion through large-permeability plasmalemmal channels ${ }^{40,41}$ ), several classes of receptors (sometimes having opposite actions) are activated at effector cells. Finally, purinoceptors are linked to an extensive array of intracellular signalling cascades that underlie their long-term trophic effects (Figure 1).

\section{Purinergic Signalling Controls Biological Defence Systems}

The ancient 'damage signaller' characteristic of ATP is evolutionarily conserved in several systems of biological defence. First, ATP functions as one of the main mediators of pain, both in acute and chronic contexts, as indeed $P 2 X_{2 / 3}$ receptors are involved in fast pain perception, ${ }^{38,42}$ whereas $\mathrm{P}_{2} \mathrm{X}_{4}$ and $\mathrm{P}_{2} \mathrm{Y}_{12}$ receptors assume a leading role in the pathogenesis of neuropathic pain. ${ }^{43-45}$

Second, purinergic agonists regulate the immune response in various tissues. In particular, in the brain and spinal cord, activation of several types of purinoceptors (most notably $\mathrm{P}_{2} \mathrm{X}_{4}, \mathrm{P}_{2} \mathrm{X}_{7}, \mathrm{P}_{2} \mathrm{Y}_{6}$ and $\mathrm{P} 2 \mathrm{Y}_{12}$ ), which occurs in a highly coordinated temporal sequence, controls motility and activation of microglia, thus being central to the brain immune response. ${ }^{46,47}$ In particular, the $\mathrm{P} 2 \mathrm{X}_{7}$ receptor seems to be critical for microglial activation by $\beta$-amyloid, being therefore pathologically relevant for Alzheimer's disease. ${ }^{48}$ Similarly, purinergic signalling is intimately involved in the activation of the peripheral immune response being not only a stimulator but also a precise regulator of the differentiation and function of immunocompetent cells, ${ }^{49,50}$ as well as in driving chemotaxis of neutrophiles, eosinophiles, macrophages and mast cells. ${ }^{51-53}$

Third, ATP and its analogues are directly involved in tissue remodelling in response to injury and have a key role in the regulation of subsequent repair and regeneration. In the nervous system, stimulation of purinoceptors triggers astrogliosis, the generalised response of astrocytes to brain damage, which is characterised by cell proliferation and remodelling of the neural circuitry. ${ }^{54,55}$ Reactive astrogliosis is instrumental for both formation of scar and limitation of the brain damaged area (through anisomorphic astrogliosis), as well as for post-insult remodelling and recovery of neural function (by isomorphic astrogliosis). The initial events in astroglial responses to purinergic signallers are often associated with $\mathrm{P}_{2} \mathrm{Y}_{1 / 2}$ receptor-mediated $\mathrm{Ca}^{2+}$ astroglial signalling in astrocytes, ${ }^{56,57}$ which, depending on the context, is instrumental for glial $\mathrm{Ca}^{2+}$ excitability or can initiate longterm effects. ${ }^{58}$ These trophic/astrogliotic effects of P2 agonists (manifested by proliferative and morphological responses) were found both in vitro, in glial cultures, and 
Table 1 Functional consequences of genetic deletion of purinoceptors

\begin{tabular}{|c|c|}
\hline $\begin{array}{l}\text { Receptor } \\
\text { subtype }\end{array}$ & Phenotype ${ }^{\text {reference }}$ \\
\hline $\begin{array}{c}\text { P1 Adenc } \\
\mathrm{A}_{1}\end{array}$ & $\begin{array}{l}\text { eceptors } \\
\text { (i) Behavioural phenotype: increased aggression and anxiety; decreased motor activity } \\
\text { (ii) Neural phenotype: neuroprotection in newborns; hyperalgesia; no inhibition of synaptic transmission; decreased long-term } \\
\text { potentiation; reduced hypoxia-associated decrease in neural activity and recovery after hypoxia } \\
\text { (iii) Kidney phenotype: absent tubuloglomerular feedback } \\
\text { (iv) Metabolic phenotype: increased insulin and glucagon secretion }{ }^{103-106}\end{array}$ \\
\hline$A_{2 A}$ & $\begin{array}{l}\text { (i) Behavioural phenotype: increased aggression and anxiety; decreased exploratory activity; attenuated psychostimulant } \\
\text { responses; decreased alcohol sensitivity and withdrawal; decreased amphetamine- and cocaine-induced locomotor response } \\
\text { (ii) Neural phenotype: neuroprotection in adults; hypoalgesia } \\
\text { (iii) Cardiovascular phenotype: increased blood pressure, heart rate and rennin activity } \\
\text { (iv) Haemostatic phenotype: increased platelet aggregation; increased brain damage after focal ischaemia } \\
\text { (v) Immunological phenotype: increased inflammatory response } \\
\text { (vi) Sensory phenotype: decreased pain threshold }\end{array}$ \\
\hline$A_{2 B}$ & (i) Immunological phenotype: increased histamine release but decreased IL-13 release from mast cells ${ }^{112,113}$ \\
\hline $\mathrm{A}_{3}$ & $\begin{array}{l}\text { (i) Behavioural phenotype: increased despair and motor activity } \\
\text { (ii) Neural phenotype: reduced neuroprotection; hyperalgesia } \\
\text { (iii) Immunological phenotype: attenuated lipopolysaccharide-induced TNF } \alpha \text { production and adenosine-induced histamine } \\
\text { release from mast cells; decreased neutrophil infiltration of damaged myocardium; decreased local inflammatory response } \\
\text { (iii) Cardiovascular phenotype: decreased infarct size following ischaemic-reperfusion injury; loss of adenosine-induced } \\
\text { cutaneous vasopermeability; i.v. adenosine produces and greater drop in blood pressure; increased tolerance to ischaemia; } \\
\text { lower intraocular pressure }\end{array}$ \\
\hline
\end{tabular}

(ii) Reproductory phenotype: male infertility due to the reduction of sperm in the ejaculate and severely impaired contractility of vas deference

(iii) haemostatic phenotype: reduced thrombosis associated with injury of the walls of small arterioles ${ }^{120-123}$

$\mathrm{P}_{2} \mathrm{X}_{2} \quad$ (i) Neural phenotype: impaired synaptic facilitation in hippocampal interneurones

(ii) Sensory phenotype: impaired taste

(iii) Chemosensory phenotype: affected excitation of afferent nerves in carotid body by hypoxia

(iv) Gut phenotype: reduced peristalsis of the small intestine ${ }^{124-126}$

$\mathrm{P}_{2} \mathrm{X}_{3} \quad$ (i) Sensory phenotype: affected nociception, impaired temperature sensitivity, impaired taste

(ii) Urinary phenotype: affected voiding reflex ${ }^{39,125,127-129}$

$\mathrm{P} 2 \mathrm{X}_{2} \& \mathrm{P} 2 \mathrm{X}_{3} \quad$ (i) Sensory phenotype: affected nociception, impaired temperature sensitivity, severely impaired taste

(ii) Chemosensory phenotype: reduced ventilatory responses to a decrease in the level of inspired $\mathrm{O}_{2}{ }^{39,125}$

${\mathrm{P} 2 \mathrm{X}_{4}} \quad$ (i) Neural phenotype: reduced hippocampal LTP

(ii) Sensory phenotype: reduced chronic pain (both inflammatory and neuropathic)

(ii) Vascular phenotype: impaired flow-sensitivity of blood vessels; decrease in NO production by endothelial cells, decreased vasodilatation, higher blood pressure ${ }^{130,131}$

$\mathrm{P}^{2} \mathrm{X}_{7} \quad$ (i) Immunological phenotype: impaired immune response

(ii) Sensory phenotype: reduced inflammatory and neuropathic chronic pain

(iii) Exocrine phenotype: impaired saliva production

(iv) Bone phenotype: abnormal bone formation and resorption ${ }^{25,132-134}$

\section{$P 2 Y$ receptors}

${\mathrm{P} 2 \mathrm{Y}_{1}}$ (i) Haemostatic phenotype: mildly prolonged bleeding times

(ii) Metabolic phenotype: increases systemic glucose levels ${ }^{21,135}$

$\mathrm{P}_{2} \mathrm{Y}_{2} \quad$ (i) Epithelial phenotype: abnormal secretion

(ii) Bone phenotype: inhibited bone formation 88,136

$\mathrm{P}_{4} \quad$ (i) Epithelial phenotype: abnormal secretion ${ }^{21,137}$

$\mathrm{P}_{6} \quad$ (i) Immunological phenotype: UDP-induced IL-6 and macrophage-inflammatory protein-2 release to lipopolysaccharide and macrophage UDP-induced inositol phosphate production are lost

(ii) Cardiovascular phenotype: loss of endothelium-dependent UDP vasodilation ${ }^{138}$

$\mathrm{P}_{12} \quad$ (i) Haemostatic phenotype: prolonged bleeding time, inhibition of platelet aggregation to ADP, and resistance to arterial thrombosis $^{139}$ 


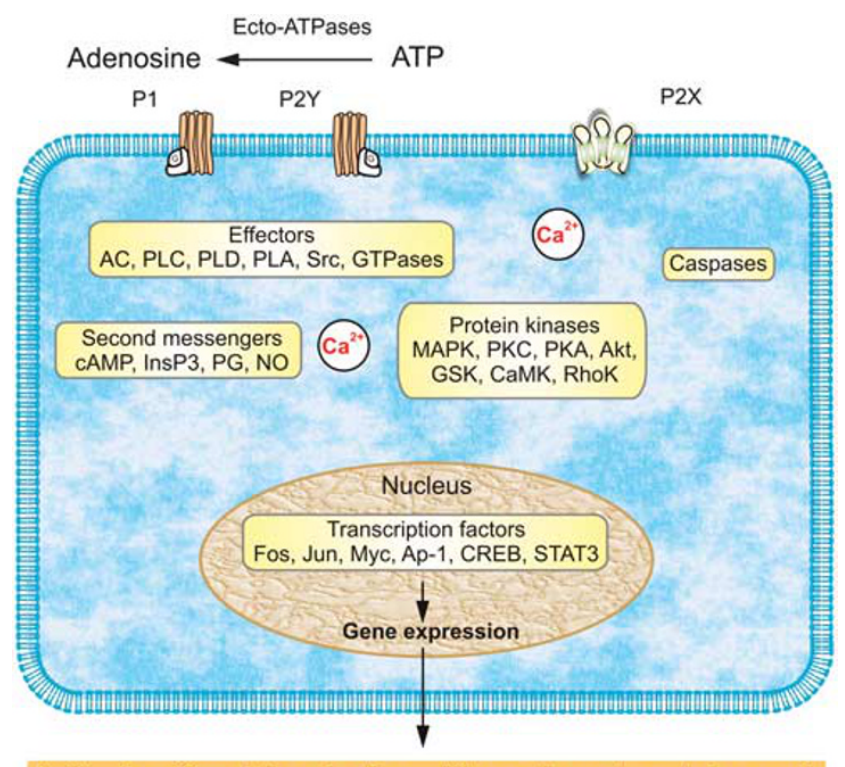

Proliferation, differentiation, migration, motility, growth arrest, apoptosis, necrosis

Figure 1 Overview of purinergic signalling mechanisms that regulate long-term, trophic effects. Extracellular nucleotides and nucleosides bind to purinoceptors coupled to signal-transducing effector molecules. Activation of effectors leads to generation of second messengers and/or stimulation of protein kinases that regulate expression of genes needed for long-term, trophic actions. Trophic action of P2X receptors can be mediated by increases in cytosolic $\mathrm{Ca}^{2+}$ concentration; activation of $\mathrm{P}_{2} \mathrm{X}_{7}$ receptors can also be coupled to protein kinase cascades and caspases that can mediate proliferation and apoptosis. Cell-specific and/or receptor subtypespecific differences are likely to account for variations in signalling pathways and functional outcomes. It should be noted that the list of elements is not meant to be all-inclusive. Other protein kinases, for example, MEK and PI3K, are upstream of the listed kinases involved in purinergic signalling, whereas others are downstream, for example, p70S6K. In addition, dashed arrows indicate that not all listed elements are activated by the upstream component, for example, not all $\mathrm{P} 1$ receptors are coupled to all listed effectors. AC, adenylyl cyclase; AP-1, activator protein-1; CaMK, calcium/calmodulin protein kinase; CREB, cAMP response element binding protein; DG, diacylglycerol; GSK, glycogen synthase kinase; InsP $\mathrm{P}_{3}$, inositol trisphosphate; MAPKs, mitogen-activated protein kinases (including extracellular signal-regulated protein kinase (ERK), p38 MAPK, and stress-activated protein kinase (SAPK)/c-Jun NH2-terminal kinase (JNK)); MEK, MAPK/ERK kinase; NO, nitric oxide; PG, prostaglandin; PI3K, phosphoinositide 3-kinase; PLC, phosphatidylinositol-specific phospholipase C; PKA, protein kinase A; PKC, protein kinase C; PLD, phospholipase D; PLA, phospholipase A; STAT3, signal transducer and activator of transcription-3 (based on Figure 11 from Burnstock ${ }^{12}$ with permission from the American Physiological Society )

in vivo, in nucleus accumbens of rats. ${ }^{17,59-61}$ Similarly, purinergic signalling has a fundamental role in remodelling and healing of lesions in other tissues, including skin and bone. In the next part of this review, we will focus on the longterm trophic roles of purines and pyrimidines in cell proliferation, differentiation and death in the turnover of epithelial cells in skin and in cells lining visceral organs, in restenosis, embryological development, bone formation and resorption and cancer.

\section{Stratified Squamous Epithelia}

Stratified squamous epithelia in several sites, including two non-keratinised cell types, namely, rat cornea and oesophagus, and four keratinised cell types, soft palate, foot pad skin, vagina and tongue, showed heavy immunostaining of the $\mathrm{P}_{2} \mathrm{X}_{5}$ receptor associated with cell differentiation in spinous and granular cell layers, but not in basal cuboidal or keratinised outer layers. In contrast, there was heavy immunostaining of $\mathrm{P}_{2} \mathrm{X}_{7}$ receptors in the outer keratinised layer, perhaps associated with apoptotic cell death. ${ }^{62}$

Rapid turnover rates are found in the epithelium of the small intestine. The crypts contain undifferentiated progenitor cells from which almost all other epithelial cell types, including goblet cells and enterocytes, arise. The differentiated cells glide towards the villus tips where they are finally ejected into the lumen. In the rat, this whole process takes 3-4 days. ${ }^{63}$ $\mathrm{P}_{2} \mathrm{X}_{5}$ receptors are expressed on the narrow 'stem' of villus goblet cells, whereas $\mathrm{P} 2 \mathrm{X}_{7}$ receptor immunoreactivity is seen only on the membranes of enterocytes and goblet cells at the tip of the villus, where cells undergo apoptosis, before shedding into the lumen. ${ }^{64}$

\section{Skin}

The expression of $\mathrm{P} 2 \mathrm{X}_{5}, \mathrm{P}_{2} \mathrm{X}_{7}$ and $\mathrm{P} 2 \mathrm{Y}_{2}$ receptor subtypes was studied in healthy human epidermal keratinocyes in relation to markers for proliferation (PCNA and Ki-67), differentiation (cytokeratin $\mathrm{KIO}$ and involucrin) and apoptosis (TUNEL and anti-caspase-3). ${ }^{65}$ It was shown that $\mathrm{P}_{2 Y_{1}}$ and $\mathrm{P}_{2} \mathrm{Y}_{2}$ receptors were immunoreactive in basal and parabasal keratinocytes, $\mathrm{P}_{2} \mathrm{X}_{5}$ receptor immunostaining within the stratum spinosum and $\mathrm{P}_{2} \mathrm{X}_{7}$ receptor immunostaining in the stratum corneum, associated with cell proliferation, differentiation and apoptotic cell death, respectively (Figure 2). Functional experiments on cultured keratinocytes were also carried out in this study, which showed the following: an increase in cell numbers in response to the $P 2 Y_{1}$ receptor agonist 2-methylthio ADP and the $\mathrm{P}_{2} \mathrm{Y}_{2}$ receptor agonist UTP; and a significant decrease in cell numbers with the $P 2 X_{5}$ receptor agonist $A T P \gamma S$ and the $\mathrm{P}_{2} \mathrm{X}_{7}$ receptor agonist BzATP (Figure 3). Later studies from this group examined the purinergic signalling profile in human fetal epidermis. ${ }^{66}$ They showed $\mathrm{P}_{2} \mathrm{Y}_{1}$ receptors in the basal layer of the developing epidermis associated with proliferation; $\mathrm{P}_{2} \mathrm{X}_{5}$ receptors predominantly in the basal and intermediate layers associated with differentiation; and $\mathrm{P}_{2} \mathrm{X}_{7}$ receptors in the periderm associated with apoptotic cell death. $\mathrm{P}_{2} \mathrm{Y}_{2}$ receptors were also found in the periderm, where they may have a role in chloride and fluid secretion into the amniotic fluid.

In a study on purinergic signalling in wound healing ${ }^{67}$ in regenerating epidermis of denervated wounds, $\mathrm{P}_{2} \mathrm{Y}_{1}$ receptor protein expression was significantly increased in keratinocytes, whereas $\mathrm{P}_{2} \mathrm{Y}_{2}$ receptor protein expression was significantly decreased. However, NGF treatment of denervated wounds reduced the expression of $\mathrm{P}_{2} \mathrm{Y}_{1}$ receptors and enhanced the expression of $\mathrm{P}_{2} \mathrm{Y}_{2}$ receptors. In innervated wounds, NGF treatment enhanced both $\mathrm{P}_{2} \mathrm{X}_{5}$ and $\mathrm{P} 2 \mathrm{Y}_{1}$ receptor proteins in keratinocytes. $\mathrm{P}_{2} \mathrm{X}_{7}$ receptors were absent in all experimental wound healing processes.

$\mathrm{P}_{2} \mathrm{X}_{5}$ and $\mathrm{P} 2 \mathrm{X}_{7}$ receptors were shown to be present in human warts and CIN612 organotypic raft cultures of human papillomavirus-infected keratinocytes and may provide a novel approach for the treatment of warts. ${ }^{68} \mathrm{P}_{2} \mathrm{Y}_{1}, \mathrm{P}_{2} \mathrm{Y}_{2}$ and $\mathrm{P}_{2} \mathrm{X}_{5}$ receptors are expressed on human anagen hair 
follicles, with $\mathrm{P}_{2} \mathrm{Y}_{1}$ receptors present in proliferating cells in the outer root sheath and bulb, whereas $\mathrm{P}_{2} \mathrm{X}_{5}$ receptors were present on the inner and outer root sheaths and medulla, and were associated with differentiation. ${ }^{65} \mathrm{P}_{2} \mathrm{Y}_{2}$ receptors were found in living cells at the edge of the cortex/medulla. P2X receptors were not present.

\section{Cancer}

There were early reports of the beneficial effect of ATP in the treatment of cancer, ${ }^{69}$ and analysis of the purinergic receptor subtypes involved in the development of tumours in the prostate, ${ }^{70}$ bladder, ${ }^{71}$ melanoma, ${ }^{72,73}$ breast $^{74-76}$ and other organs has been described (see review by White and Burnstock ${ }^{77}$ ). Again, it was shown that $P 2 Y_{1}$ and $P 2 Y_{2}$ receptors were expressed and involved in cell proliferation, $\mathrm{P}_{2} \mathrm{X}_{5}$ receptors were involved in differentiation (and were therefore antiproliferative) and $\mathrm{P} 2 \mathrm{X}_{7}$ receptors were involved in cell death (Figure 4). Human melanomas express functional $\mathrm{P}_{2 \mathrm{X}_{7}}$ receptors that mediate the apoptotic functions of ATP, ${ }^{72}$ whereas $\mathrm{P}_{2} \mathrm{Y}_{1}$ and $\mathrm{P}_{2} \mathrm{Y}_{2}$ receptor agonists caused a decrease and increase in cell numbers, respectively. ${ }^{73}$ In human squamous cell carcinoma, $\mathrm{P}_{2} \mathrm{Y}_{2}, \mathrm{P}_{2} \mathrm{X}_{5}$ and $\mathrm{P} 2 \mathrm{X}_{7}$ receptors seem to be associated with proliferation, differentiation and cell death, respectively. ${ }^{78}$
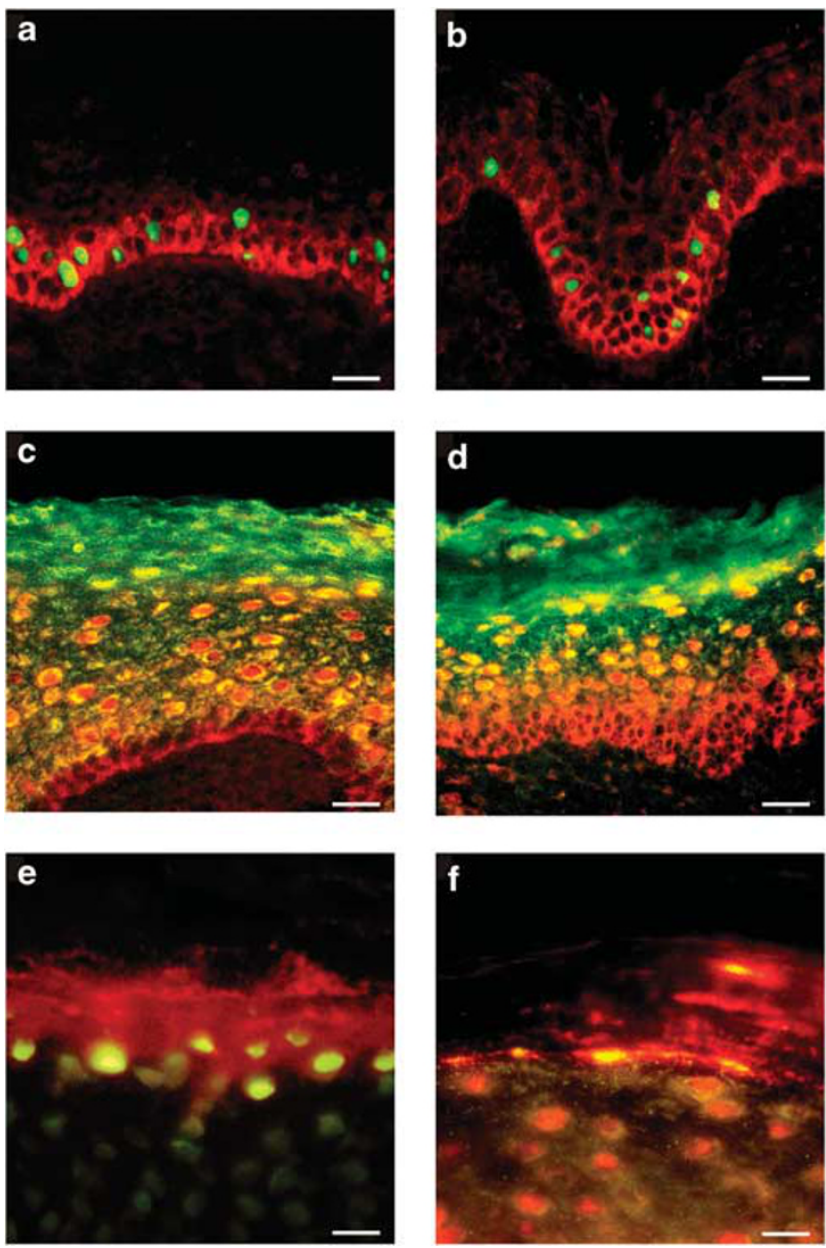

In high-grade bladder cancer, using the HT-1376 cell line, $\mathrm{P}_{2} \mathrm{X}_{5}$ and $\mathrm{P}_{2} \mathrm{Y}_{11}$ receptors were shown to mediate the antineoplastic effects of ATP, whereas $\mathrm{P}_{2} \mathrm{X}_{7}$ receptors mediated apoptotic cell death. ${ }^{71}$ Similar results are described for cell lines of hormone-refractory prostate cancer ${ }^{79}$ and ATP was shown to reduce the in vivo growth of advanced hormonerefractory prostate cancer implanted into mice. ${ }^{80}$

Finally, several clinical trials have demonstrated that systemic administration of ATP may have beneficial effects (prolongation of survival and reduced cachexia) in inoperable lung cancer patients (for details see White and Burnstock ${ }^{77}$ ).

\section{Long-Term Purinergic Signalling in Embryological Development}

The transient appearance of $\mathrm{P} 2$ receptors during both embryological and postnatal development suggests that ATP is involved in the sequential proliferation, differentiation, motility and death of cells during the complex events involved in development ${ }^{12,81,82}$. For example, a novel $\mathrm{P} 2 \mathrm{Y}_{8}$ receptor was cloned in Xenopus embryos and was shown to be transiently expressed in the neural plate and tube from stages 13-18 and again at stage 28, when secondary neurulation occurs in the tail bud, suggesting an involvement of this receptor in the development of the nervous system. ${ }^{83} \mathrm{P}_{2} \mathrm{Y}_{1}$ receptors were transiently expressed in the limb buds of chick

Figure 2 Double labelling of $\mathrm{P}_{2} \mathrm{Y}_{1}$ and $\mathrm{P}_{2} \mathrm{Y}_{2}$ receptors with markers of proliferation shows colocalisation within a sub-population of basal and parabasal keratinocytes. Double labelling of $\mathrm{P} 2 \mathrm{X}_{5}$ receptors with markers of differentiated keratinocytes shows colocalisation within the stratum spinosum, and double labelling of $\mathrm{P} 2 \mathrm{X}_{7}$ receptors with markers of apoptosis in human leg skin shows colocalisation within the stratum corneum. (a) Ki-67 immunolabelling (a marker for proliferation) stained the nuclei (green) of a sub-population of keratinocytes in the basal and parabasal layers of the epidermis. $P_{2} Y_{1}$ receptor immunostaining (red) was found in the basal layer on cells also staining for Ki67. Scale bar $30 \mu \mathrm{m}$. (b) PCNA immunolabelling (a marker for proliferation) stained the nuclei (green) of a sub-population of keratinocytes. These nuclei were often distributed in clusters and found in the basal and parabasal layers of the epidermis. $\mathrm{P}_{2} \mathrm{Y}_{2}$ receptor immunostaining (red) was also expressed in basal and parabasal epidermal cells. Scale bar $30 \mu \mathrm{m}$. (c) P2X $\mathrm{X}_{5}$ receptor immunostaining (red) showed overlap (yellow) with cytokeratin $\mathrm{K} 10$ (green), an early marker of keratinocyte differentiation. P2X receptors were present in the basal layer of the epidermis up to the mid-granular layer. Cytokeratin K10 was distributed in most suprabasal keratinocytes. The stratum basale stained only for $\mathrm{P}_{2} \mathrm{X}_{5}$ receptors, indicating that no differentiation was taking place in these cells. The colocalisation of $\mathrm{P} 2 \mathrm{X}_{5}$ receptors and cytokeratin $\mathrm{K} 10$ appeared mainly in the cytoplasm of differentiating cells within the stratum spinosum and partly in the stratum granulosum. Note that the stratum corneum also stained for cytokeratin $\mathrm{K} 10$, which labelled differentiated keratinocytes, even in dying cells. Scale bar $30 \mu \mathrm{m}$. (d) P2X $X_{5}$ receptor immunostaining (red) showed overlap (yellow) with involucrin (green). $P 2 X_{5}$ receptors were present in the basal layer of the epidermis up to the mid-granular layer. Note that the pattern of staining with involucrin was similar to that seen with cytokeratin $\mathrm{K} 10$, except that cells from the stratum basale up to the midstratum spinosum were not labelled with involucrin, which is a late marker of keratinocyte differentiation. Scale bar $30 \mu \mathrm{m}$. (e) TUNEL (green) labelled the nuclei of cells at the uppermost level of the stratum granulosum and $\mathrm{P} 2 \mathrm{X}_{7}$ antibody (red) mainly stained cell fragments within the stratum corneum. Scale bar $15 \mu \mathrm{m}$. (f) Anti-caspase-3 (green) colocalised with areas of $\mathrm{P}_{2} \mathrm{X}_{7}$ receptor immunostaining (red) both at the junction of the stratum granulosum and within the stratum corneum. Areas of colocalisation were yellow. Note that the differentiating keratinocytes in the upper stratum granulosum were also positive for anti-caspase3. Scale bar $15 \mu \mathrm{m}$ (reproduced with permission from Greig et al..$^{140}$ ) 

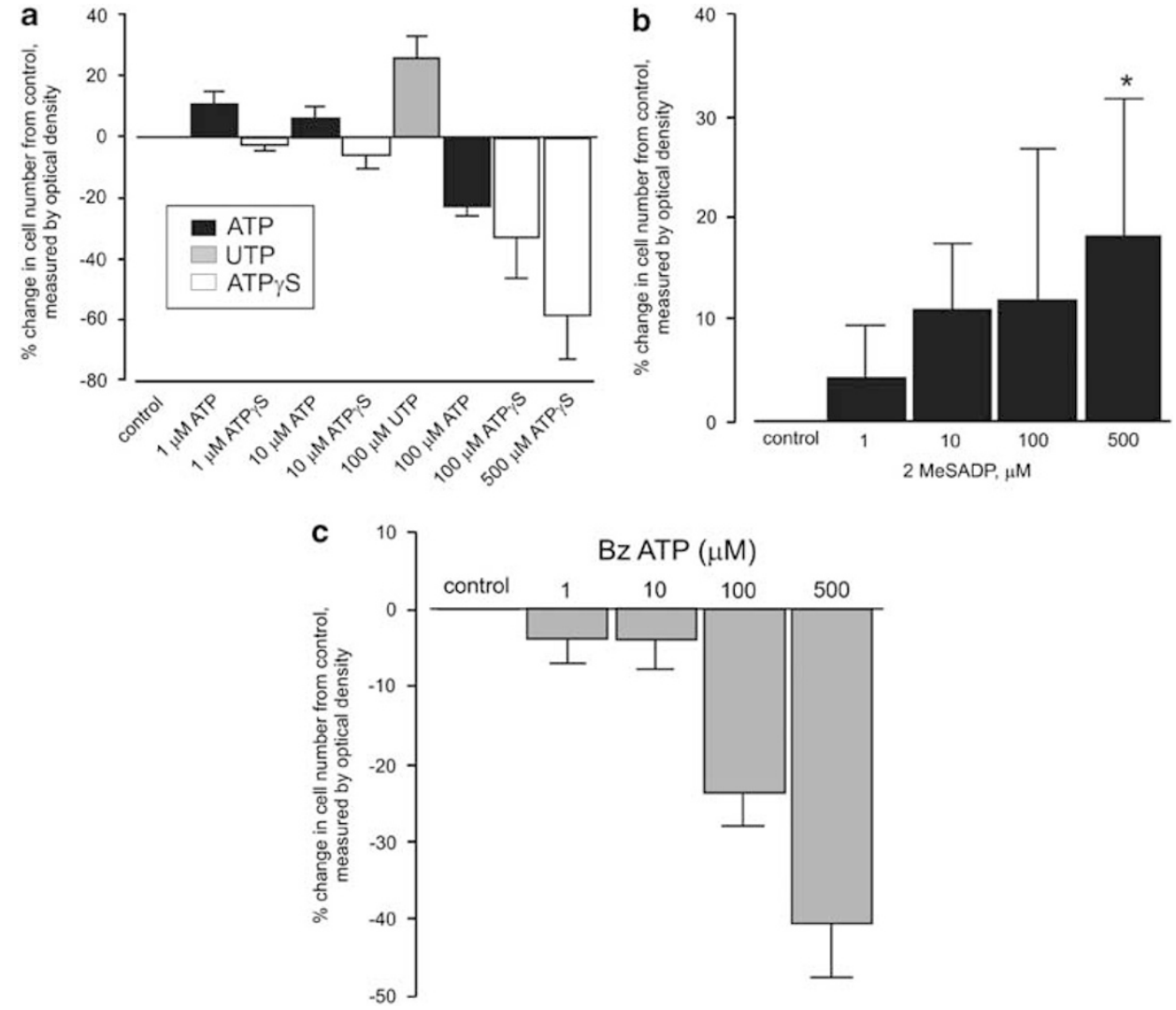

Figure 3 At $48 \mathrm{~h}$ after application of drugs to primary human keratinocyte cultures. (a) ATP (1-10 $\mu \mathrm{M})$ and UTP $(100 \mu \mathrm{M})$ cause an increase in cell number, whereas ATP $\gamma S(100-500 \mu \mathrm{M})$ and ATP $(100 \mu \mathrm{M})$ cause a significant decrease. Results represent the mean of eight experiments. ${ }^{*} P<0.001$ compared with that of control. (b) $2 \mathrm{MeSADP}(500 \mu \mathrm{M})$ causes a significant increase in cell number. Results represent the mean of eight experiments. ${ }^{*} P<0.05$ compared with that of control. (c) BzATP $(100-500 \mu \mathrm{M})$ causes a significant decrease in cell number. Results represent the mean of nine experiments. ${ }^{*} P<0.001$ compared with that of control. Error bars represent mean \pm S.E.M (reproduced with permission from Greig et al. ${ }^{140}$ )

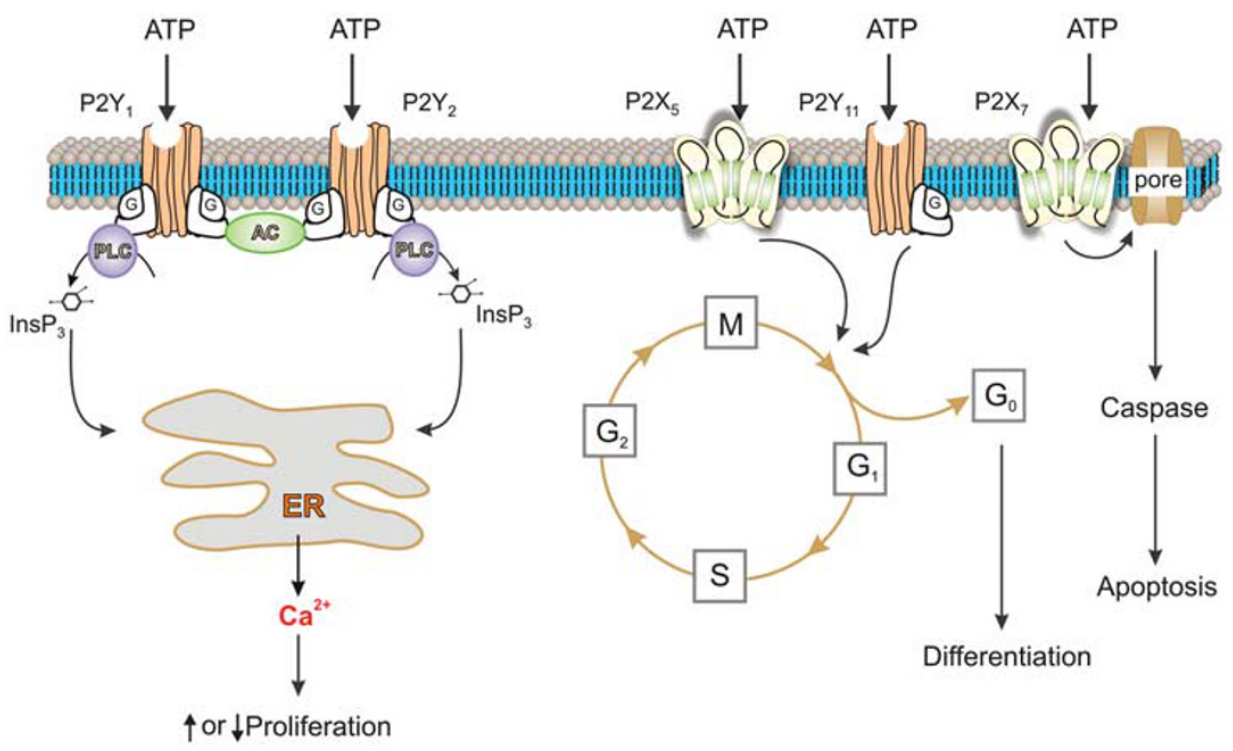

Figure 4 Schematic diagram illustrating the different mechanisms by which $P 2$ receptor subtypes might alter cancer cell function. $P 2 Y_{1}$ and $P 2 Y_{2}$ receptors could affect the rate of cell proliferation through altering the intracellular levels of CAMP by modulating adenylyl cyclase $(A C)$ or by increasing intracellular calcium levels through the phospholipase $\mathrm{C}(\mathrm{PLC})$ pathway. $\mathrm{P}_{2} \mathrm{X}_{5}$ and $\mathrm{P}_{2} \mathrm{Y}_{11}$ receptor activation might switch the cell cycle from proliferation into a state of differentiation. The $\mathrm{P} 2 \mathrm{X}_{7}$ receptor activates the apoptotic caspase enzyme system (redrawn from White and Burnstock ${ }^{77}$ with permission from Elsevier) 


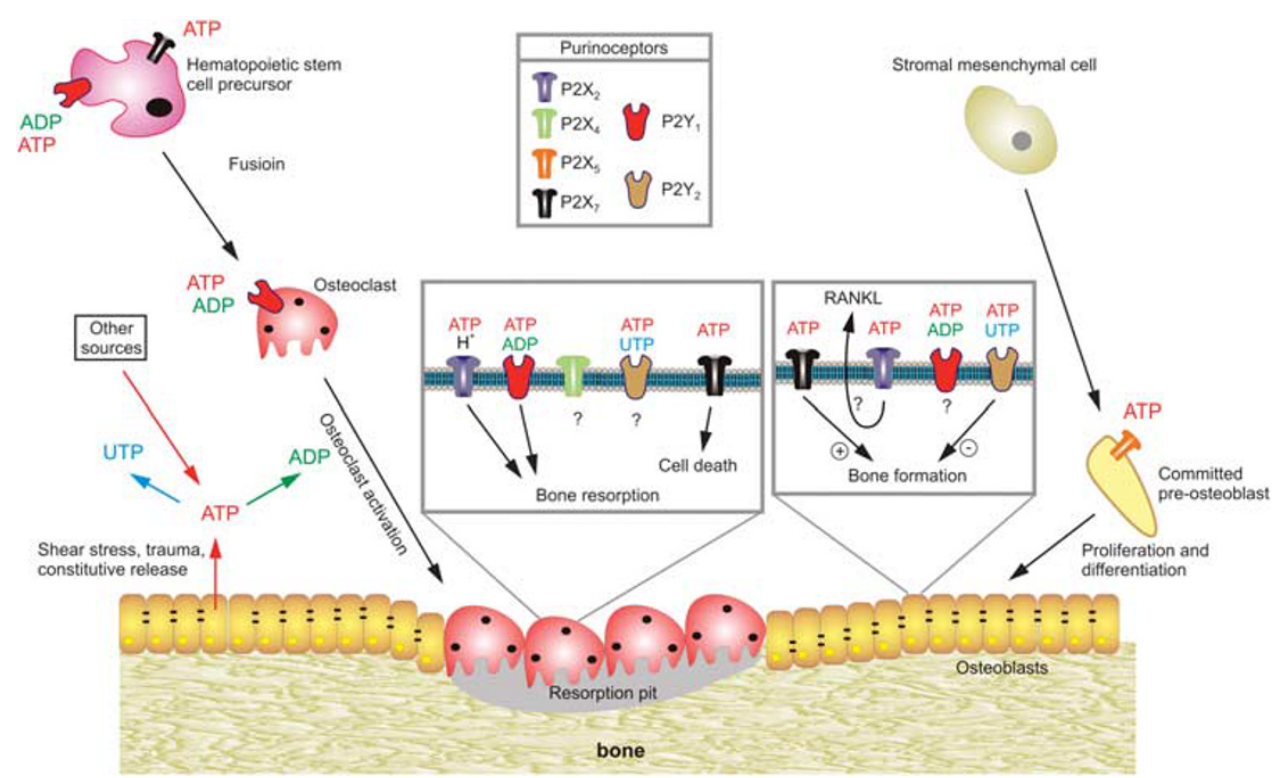

Figure 5 Schematic diagram illustrating the potential functions of extracellular nucleotides and P2 receptors in modulating bone cell function. ATP released from osteoclasts (e.g., through shear stress or constitutively) or from other sources, can be degraded to adenosine $5^{\prime}$-diphosphate (ADP) or converted into uridine $5^{\prime}$-triphosphate (UTP) through ecto-nucleotidases. All three nucleotides can function separately on specific P2 receptor subtypes, as indicated by the colour coding. ATP is a universal agonist, whereas UTP is only active at the $P 2 Y_{2}$ receptor and ADP is only active at the $P_{2} Y_{1}$ receptor. ADP acting on P2Y, receptors seems to stimulate both the formation (i.e., fusion) of osteoclasts from haematopoietic precursors and the resorptive activity of mature osteoclasts. For the latter, a synergistic action of ATP and protons has been proposed by the $\mathrm{P} 2 \mathrm{X}_{2}$ receptor. ADP could also stimulate resorption indirectly through actions on osteoclasts, which in turn release pro-resorptive factors (e.g., receptor activator of nuclear factor $\kappa \mathrm{B}$ ligand, RANKL) ATP at high concentrations might facilitate fusion of osteoclast progenitors through $\mathrm{P}_{2} \mathrm{X}_{7}$ receptor pore formation or induce cell death of mature

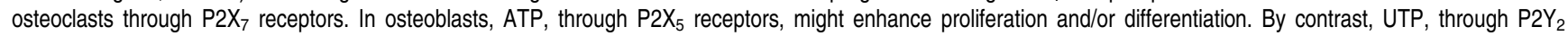

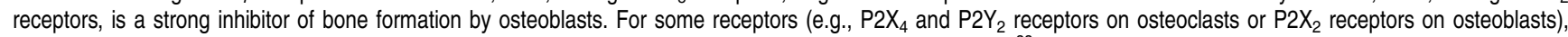
evidence for expression has been found but their role is still unclear (based on schemes from Hoebertz et al. ${ }^{88}$ )

embryos and were shown to mediate rapid cell proliferation. ${ }^{84}$ Changes in expression in P2X receptor subtypes during postnatal development of cerebellum have been described. ${ }^{85}$ Transient changes in $\mathrm{P} 2 \mathrm{X}$ receptor subtype expression during the development of skeletal muscle have been described. ${ }^{86}$ $\mathrm{P}_{2} \mathrm{X}_{5}$ receptors were present during the early development of the myotube, followed by $\mathrm{P}^{2} \mathrm{X}_{6}$ receptor expression and then, during the development of the neuromuscular junction, $\mathrm{P}_{2} \mathrm{X}_{2}$ receptors were expressed. In the chicken retina, ATP-evoked $\mathrm{Ca}^{2+}$ transients were strongest as early as E3 and were drastically reduced at E11-13.5. ${ }^{87}$ Nucleotide signalling in development probably involves a cross-talk between several other signalling pathways, including growth factors, cytokines and extracellular matrix components. ${ }^{82}$

\section{Trophic Purinergic Signalling in Bone Formation and Resorption}

Activation of $\mathrm{P}_{2} \mathrm{Y}_{1}$ receptors by ADP stimulates osteoclast activity and bone resorption (Figure 5), whereas ATP and UTP signalling through $\mathrm{P}_{2} \mathrm{Y}_{2}$ receptors in osteoblasts inhibits bone growth and mineralisation. ${ }^{88}$ More recently, $\mathrm{P}_{2} \mathrm{X}_{7}$ receptors have been shown to have trophic regulatory roles in bone formation and resorption. ${ }^{89,90} \mathrm{P}_{2} \mathrm{X}_{7}$ receptor activation of osteoblasts enhances differentiation and bone formation, ${ }^{91}$ whereas $\mathrm{P}_{2} \mathrm{X}_{7}$ receptor activation of osteoclasts results in apoptosis and bone resorption. ${ }^{92-94}$

\section{Long-Term Trophic Actions of Purines and Pyrimidines in the Pathogenesis of Atherosclerosis and Post- Angioplasty Restenosis}

ATP and UTP, acting through $\mathrm{P}_{2} \mathrm{Y}_{2}$ receptors, cause proliferation of vascular smooth muscle cells and proliferation of endothelial cells through $\mathrm{P}_{2} \mathrm{Y}_{1}$ receptors. Adenosine acting through $\mathrm{A}_{2}$ receptors inhibits smooth muscle proliferation but stimulates endothelial cell proliferation. ${ }^{95}$ The increase in vascular smooth muscle and endothelial cells in both atherosclerosis and hypertension may be mediated by the trophic actions of purines and pyrimidines released from nerves and endothelial cells ${ }^{96-98}$ and in post-angioplasty restenosis. ${ }^{99} \mathrm{P}_{2} \mathrm{Y}_{4}$ receptors seem to be regulators of angiogenesis. ${ }^{100}$ ATP increases DNA synthesis and migration of vascular endothelial cells in vasa vasorum in diseased pulmonary vessels. ${ }^{101}$ Diabetic patients express microvascular disease characterised by an increased wall-lumen ratio, mainly because of an increase in vascular smooth muscle cells, and have higher rates of restenosis after angioplasty. High glucose-induced release of ATP exerts an effect on P2Y receptors to stimulate vascular smooth muscle cell growth. ${ }^{102}$

\section{Conclusions}

Purinergic signalling, mediated by ATP, related nucleotides and adenosine, operates in all types of tissues and cells. Purinergic agonists mediate fast cell signalling, and exert 
numerous long-term trophic effects, involved in regulation of cell replication, proliferation, differentiation and death. It is hoped that there will be further exploration of the roles of this primitive and widespread signalling system in cell biology.

\section{Conflict of interest}

The authors declare no conflict of interest.

1. Lohmann K. Uber die Pyrophosphatfraktion im Muskel. Naturwissenschaften 1929; 17: 624-625.

2. Fiske CH, SubbaRow Y. Phosphorous compounds of muscle and liver. Science 1929; 70 : 381-382.

3. Lippman F. Metabolic generation and utilization of phosphate bond energy. Enzymology 1941; 1: 99.

4. Ponnamperuma C, Sagan C, Mariner R. Synthesis of adenosine triphosphate under possible primitive earth conditions. Nature 1963; 199: 222-226.

5. Waldrop MM. Did life really start out in an RNA world? Science 1989; 246: 1248-1249.

6. Wilson JE. Some thoughts on the evolutionary basis for the prominent role of ATP and ADP in cellular energy metabolism. J Theor Biol 1984; 111: 615-623.

7. Sutherland EW, Rall TW. Fractionation and characterization of a cyclic adenine ribonucleotide formed by tissue particles. J Biol Chem 1958; 232: 1077-1091.

8. Burnstock G, Verkhratsky A. Evolutionary origins of the purinergic signalling system. Acta Physiol (Oxf) 2009; 195: 415-447.

9. Drury AN, Szent-Györgyi A. The physiological activity of adenine compounds with special reference to their action upon mamalian heart. J Physiol (London) 1929; 68: 213-237.

10. Burnstock G, Campbell G, Satchell D, Smythe A. Evidence that adenosine triphosphate or a related nucleotide is the transmitter substance released by non-adrenergic inhibitory nerves in the gut. Br J Pharmacol 1970; 40: 668-688.

11. Burnstock G. Purinergic nerves. Pharmacol Rev 1972; 24: 509-581.

12. Burnstock G. Physiology and pathophysiology of purinergic neurotransmission. Physiol Rev 2007; 87: 659-797.

13. Abbracchio MP, Burnstock G, Verkhratsky A, Zimmermann H. Purinergic signalling in the nervous system: an overview. Trends Neurosci 2009; 32: 19-29.

14. North RA, Verkhratsky A. Purinergic transmission in the central nervous system. Pflugers Arch 2006; 452: 479-485.

15. Burnstock $G$, Knight GE. Cellular distribution and functions of $P 2$ receptor subtypes in different systems. Int Rev Cytol 2004; 240: 31-304.

16. Abbracchio MP, Burnstock G. Purinergic signalling: pathophysiological roles. Jpn $J$ Pharmacol 1998; 78: 113-145.

17. Neary JT, Rathbone MP, Cattabeni F, Abbracchio MP, Burnstock G. Trophic actions of extracellular nucleotides and nucleosides on glial and neuronal cells. Trends Neurosci 1996; 19: 13-18.

18. Burnstock $G$. A basis for distinguishing two types of purinergic receptor. In: Straub RW, Bolis L (eds). Cell Membrane Receptors for Drugs and Hormones: A Multidisciplinary Approach. Raven Press: New York, 1978, pp 107-118.

19. Burnstock G, Kennedy $C$. Is there a basis for distinguishing two types of P2-purinoceptor? Gen Pharmacol 1985; 16: 433-440.

20. Fredholm BB, AP IJ, Jacobson KA, Klotz KN, Linden J. International Union of Pharmacology. XXV. Nomenclature and classification of adenosine receptors. Pharmacol Rev 2001; 53: 527-552.

21. Abbracchio MP, Burnstock G, Boeynaems JM, Barnard EA, Boyer JL, Kennedy C et al. International Union of Pharmacology LVIII: update on the P2Y G protein-coupled nucleotide receptors: from molecular mechanisms and pathophysiology to therapy. Pharmacol Rev 2006; 58: 281-341.

22. Khakh BS, Burnstock G, Kennedy C, King BF, North RA, Seguela P et al. International union of pharmacology. XXIV. Current status of the nomenclature and properties of P2X receptors and their subunits. Pharmacol Rev 2001; 53: 107-118.

23. Ralevic V, Burnstock G. Receptors for purines and pyrimidines. Pharmacol Rev 1998; 50 : 413-492.

24. Fredholm BB, Arslan G, Halldner L, Kull B, Schulte G, Wasserman W. Structure and function of adenosine receptors and their genes. Naunyn Schmiedebergs Arch Pharmacol 2000; 362: 364-374

25. Surprenant A, North RA. Signaling at purinergic P2X receptors. Annu Rev Physiol 2009; 71: 333-359.

26. Burnstock G. Purine and pyrimidine receptors. Cell Mol Life Sci 2007; 64: 1471-1483.

27. Fountain SJ, Cao L, Young MT, North RA. Permeation properties of a P2X receptor in the green algae Ostreococcus tauri. J Biol Chem 2008; 283: 15122-15126.

28. Fountain SJ, Parkinson K, Young MT, Cao L, Thompson CR, North RA. An intracellular $\mathrm{P} 2 \mathrm{X}$ receptor required for osmoregulation in Dictyostelium discoideum. Nature 2007; 448 : 200-203.

29. Ludlow MJ, Traynor D, Fisher PR, Ennion SJ. Purinergic-mediated $\mathrm{Ca}^{2+}$ influx in Dictyostelium discoideum. Cell Calcium 2008; 44: 567-579.
30. Clark G, Roux SJ. Extracellular nucleotides: ancient signaling molecules. Plant Sci 2009 177: 239244

31. Gonzales EB, Kawate T, Gouaux E. Pore architecture and ion sites in acid-sensing ion channels and P2X receptors. Nature 2009; 460: 599-604.

32. Kawate T, Michel JC, Birdsong WT, Gouaux E. Crystal structure of the ATP-gated P2X ion channel in the closed state. Nature 2009; 460: 592-598.

33. North RA. Molecular physiology of P2X receptors. Physiol Rev 2002; 82: 1013-1067.

34. Pankratov $Y$, Lalo U, Krishtal OA, Verkhratsky A. P2X receptors and synaptic plasticity. Neuroscience 2009; 158: 137-148.

35. Pankratov $Y$, Lalo U, Krishtal O, Verkhratsky A. Ionotropic P2X purinoreceptors mediate synaptic transmission in rat pyramidal neurones of layer II/III of somato-sensory cortex. J Physiol 2002; 542: 529-536.

36. Verkhratsky A, Krishtal OA, Burnstock G. Purinoceptors on neuroglia. Mol Neurobiol 2009; 39: 190-208

37. Burnstock G. Purines and sensory nerves. Handb Exp Pharmacol 2009; 194: 333-392.

38. Burnstock G. Purinergic receptors and pain. Curr Pharm Des 2009; 15: 1717-1735.

39. Gourine AV, Wood JD, Burnstock G. Purinergic signalling in autonomic control. Trends Neurosci 2009; 32: 241-248.

40. Pankratov Y, Lalo U, Verkhratsky A, North RA. Vesicular release of ATP at central synapses. Pflugers Arch 2006; 452: 589-597.

41. Pankratov Y, Lalo U, Verkhratsky A, North RA. Quantal release of ATP in mouse cortex J Gen Physiol 2007; 129: 257-265.

42. Burnstock $G$. A unifying purinergic hypothesis for the initiation of pain. Lancet 1996; 347 : 1604-1605.

43. Inoue K. ATP receptors of microglia involved in pain. Novartis Found Symp 2006; 276 263-272; discussion 273-281.

44. Inoue K, Tsuda M. Microglia and neuropathic pain. Glia 2009; 57: 1469-1479.

45. Inoue K, Tsuda M, Koizumi S. ATP receptors in pain sensation: involvement of spinal microglia and $\mathrm{P}_{2} \mathrm{X}_{4}$ receptors. Purinergic Signal 2005; 1: 95-100.

46. Hanisch UK, Kettenmann H. Microglia: active sensor and versatile effector cells in the normal and pathologic brain. Nat Neurosci 2007; 10: 1387-1394.

47. Di Virgilio F, Ceruti S, Bramanti $P$, Abbracchio MP. Purinergic signalling in inflammation of the central nervous system. Trends Neurosci 2009; 32: 79-87.

48. Sanz JM, Chiozzi P, Ferrari D, Colaianna M, Idzko M, Falzoni S et al. Activation of microglia by amyloid b requires ${\mathrm{P} 2 \mathrm{X}_{7}}_{7}$ receptor expression. J Immunol 2009; 182 4378-4385.

49. Trautmann A. Extracellular ATP in the immune system: more than just a 'danger signal'. Sci Signal 2009; 2: pe6.

50. Bours MJ, Swennen EL, Di Virgilio F, Cronstein BN, Dagnelie PC. Adenosine 5'triphosphate and adenosine as endogenous signaling molecules in immunity and inflammation. Pharmacol Ther 2006; 112: 358-404.

51. Burgers JA, Schweizer RC, Koenderman L, Bruijnzeel PL, Akkerman JW. Human platelets secrete chemotactic activity for eosinophils. Blood 1993; 81: 49-55.

52. Verghese MW, Kneisler TB, Boucheron JA. P2U agonists induce chemotaxis and actin polymerization in human neutrophils and differentiated HL60 cells. J Biol Chem 1996; 271: 15597-15601.

53. Di Virgilio F. Dr. Jekyll/Mr. Hyde: the dual role of extracellular ATP. J Auton Nerv Syst 2000; 81: 59-63.

54. Giaume C, Kirchhoff F, Matute C, Reichenbach A, Verkhratsky A. Glia: the fulcrum of brain diseases. Cell Death Differ 2007; 14: 1324-1335.

55. Li L, Lundkvist A, Andersson D, Wilhelmsson U, Nagai N, Pardo AC et al. Protective role of reactive astrocytes in brain ischemia. J Cereb Blood Flow Metab 2008; 28 : 468-481.

56. Kirischuk S, Moller T, Voitenko N, Kettenmann H, Verkhratsky A. ATP-induced cytoplasmic calcium mobilization in Bergmann glial cells. J Neurosci 1995; 15: 7861-7871.

57. Kirischuk S, Scherer J, Kettenmann H, Verkhratsky A. Activation of P2-purinoreceptors triggered $\mathrm{Ca}^{2+}$ release from $\mathrm{Ins}_{3}$-sensitive internal stores in mammalian oligodendrocytes. J Physiol 1995; 483: 41-57.

58. Abbracchio MP, Verderio C. Pathophysiological roles of P2 receptors in glial cells. Novartis Found Symp 2006; 276: 91-103; discussion 103-112, 275-181.

59. Abbracchio MP, Ceruti S. Roles of P2 receptors in glial cells: focus on astrocytes. Purinergic Signal 2006; 2: 595-604.

60. Abbracchio MP, Saffrey MJ, Hopker V, Burnstock G. Modulation of astroglial cell proliferation by analogues of adenosine and ATP in primary cultures of rat striatum. Neuroscience 1994; 59: 67-76.

61. Franke H, Krugel U, Schmidt R, Grosche J, Reichenbach A, Illes P. P2 receptor-types involved in astrogliosis in vivo. Br J Pharmacol 2001; 134: 1180-1189.

62. Groschel-Stewart U, Bardini M, Robson T, Burnstock G. Localisation of P2X $X_{5}$ and $P 2 X_{7}$ receptors by immunohistochemistry in rat stratified squamous epithelia. Cell Tissue Res 1999; 296: 599-605.

63. Madara JL. Functional morphology of epithelium of the small intestine. In: Fields $\mathrm{H}$, Frizzell RA, Schultz SG (eds). Handbook of Physiology, Section 6: The Gastrointestinal System Volume IV: Intestinal Absorption and Secretion. American Physiological Society: Bethesda, MD, 1991, pp 83-120.

64. Groschel-Stewart U, Bardini M, Robson T, Burnstock G. P2X receptors in the rat duodenal villus. Cell Tissue Res 1999; 297: 111-117. 
65. Greig AV, Linge C, Burnstock G. Purinergic receptors are part of a signalling system for proliferation and differentiation in distinct cell lineages in human anagen hair follicles. Purinergic Signal 2008; 4: 331-338.

66. Greig AV, Linge C, Cambrey A, Burnstock G. Purinergic receptors are part of a signaling system for keratinocyte proliferation, differentiation, and apoptosis in human fetal epidermis. J Invest Dermatol 2003; 121: 1145-1149.

67. Greig AV, James SE, McGrouther DA, Terenghi G, Burnstock G. Purinergic receptor expression in the regeneration epidermis in a rat model of normal and delayed wound healing. Exp Dermatol 2003; 12: 860-871.

68. Greig AV, Cuthill S, Linge C, Clayton E, Burnstock G. $P 2 X_{5}$ and $P 2 X_{7}$ receptors in human warts and $\mathrm{CIN}-612$ organotypic raft cultures of human papillomavirus infected keratinocytes. Purinergic Signal 2006; 2: 509-515.

69. Rapaport E. Treatment of human tumor cells with ADP or ATP yields arrest of growth in the S phase of the cell cycle. J Cell Physiol 1983; 114: 279-283.

70. Janssens R, Boeynaems JM. Effects of extracellular nucleotides and nucleosides on prostate carcinoma cells. Br J Pharmacol 2001; 132: 536-546.

71. Shabbir M, Ryten M, Thompson C, Mikhailidis D, Burnstock G. Purinergic receptor-mediated effects of ATP in high-grade bladder cancer. BJU Int 2008; 101: 106-112.

72. White N, Butler PE, Burnstock G. Human melanomas express functional $P 2 X_{7}$ receptors. Cell Tissue Res 2005; 321: 411-418.

73. White N, Ryten M, Clayton E, Butler $P$, Burnstock $G$. P2Y purinergic receptors regulate the growth of human melanomas. Cancer Lett 2005; 224: 81-91.

74. Dixon CJ, Bowler WB, Fleetwood P, Ginty AF, Gallagher JA, Carron JA. Extracellular nucleotides stimulate proliferation in MCF-7 breast cancer cells via P2-purinoceptors. $\mathrm{Br} J$ Cancer 1997; 75: 34-39.

75. Gow IF, Thomson J, Davidson J, Shennan DB. The effect of a hyposmotic shock and purinergic agonists on $\mathrm{K}^{+}\left(\mathrm{Rb}^{+}\right)$efflux from cultured human breast cancer cells. Biochim Biophys Acta 2005; 1712: 52-61.

76. Vandewalle B, Hornez L, Revillion F, Lefebvre J. Effect of extracellular ATP on breast tumor cell growth, implication of intracellular calcium. Cancer Lett 1994; 85: 47-54.

77. White N, Burnstock G. P2 receptors and cancer. Trends Pharmacol Sci 2006; 27: $211-217$

78. Greig AV, Linge C, Healy V, Lim P, Clayton E, Rustin MH et al. Expression of purinergic receptors in non-melanoma skin cancers and their functional roles in A431 cells. J Invest Dermatol 2003; 121: 315-327.

79. Shabbir M, Ryten M, Thompson C, Mikhailidis D, Burnstock G. Characterization of calcium-independent purinergic receptor-mediated apoptosis in hormone-refractory prostate cancer. BJU Int 2008; 101: 352-359.

80. Shabbir M, Thompson C, Jarmulowiczc M, Mikhailidis D, Burnstock G. Effect of extracellular ATP on the growth of hormone-refractory prostate cancer in vivo. BJU Int 2008; 102: 108-112.

81. Burnstock G. Purinergic signalling in development. In: Abbracchio MP, Williams M (eds) Handbook of Experimental Pharmacology, Volume 151/I Purinergic and Pyrimidinergic Signalling I - Molecular, Nervous and Urinogenitary System Function. Springer-Verlag: Berlin, 2001, pp 89-127.

82. Zimmermann $\mathrm{H}$. Nucleotide signaling in nervous system development. Pflugers Arch 2006; 452: 573-588

83. Bogdanov YD, Dale L, King BF, Whittock N, Burnstock G. Early expression of a nove nucleotide receptor in the neural plate of Xenopus embryos. J Biol Chem 1997; 272 12583-12590.

84. Meyer MP, Clarke JD, Patel K, Townsend-Nicholson A, Burnstock G. Selective expression of purinoceptor $\mathrm{CP}_{2} \mathrm{Y}_{1}$ suggests a role for nucleotide signalling in development of the chick embryo. Dev Dyn 1999; 214: 152-158.

85. Xiang Z, Burnstock $G$. Changes in expression of $P 2 X$ purinoceptors in rat cerebellum during postnatal development. Brain Res Dev Brain Res 2005; 156: 147-157.

86. Ryten M, Hoebertz A, Burnstock G. Sequential expression of three recepto subtypes for extracellular ATP in developing rat skeletal muscle. Dev Dyn 2001; 221 331-341.

87. Sugioka M, Fukuda $\mathrm{Y}$, Yamashita $\mathrm{M} . \mathrm{Ca}^{2+}$ responses to ATP via purinoceptors in the early embryonic chick retina. J Physiol 1996; 493: 855-863.

88. Hoebertz A, Arnett TR, Burnstock G. Regulation of bone resorption and formation by purines and pyrimidines. Trends Pharmacol Sci 2003; 24: 290-297.

89. Grol MW, Panupinthu N, Korcok J, Sims SM, Dixon SJ. Expression, signaling, and function of $\mathrm{P} 2 \mathrm{X}_{7}$ receptors in bone. Purinergic Signal 2009; 5: 205-221.

90. Li J, Meyer R, Duncan RL, Turner $\mathrm{CH}$. P2X nucleotide receptor plays an important role in callus remodeling during fracture repair. Calcif Tissue Int 2009; 84 405-412.

91. Panupinthu N, Rogers JT, Zhao L, Solano-Flores LP, Possmayer F, Sims SM et al. P2X receptors on osteoblasts couple to production of lysophosphatidic acid: a signaling axis promoting osteogenesis. J Cell Biol 2008; 181: 859-871.

92. Gartland A, Ginty AF, Gallagher JA, Bowler WB. Activation of $P 2 X_{7}$ receptors expressed by human osteoclastoma modulates bone resorption. Calci Tissue Int 1999; 64: S56.

93. Korcok J, Sims SM, Dixon SJ. P2X 7 nucleotide receptors act through two distinct mechanisms to regulate osteoclast survival. J Bone Miner Res 2004; 19 S418-S419.
94. Ohlendorff SD, Tofteng $\mathrm{CL}$, Jensen JE, Petersen S, Civitelli R, Fenger $\mathrm{M}$ et al. Single nucleotide polymorphisms in the $\mathrm{P} 2 \mathrm{X}_{7}$ gene are associated to fracture risk and to effect of estrogen treatment. Pharmacogenet Genomics 2007; 17: 555-567.

95. Burnstock G. Purinergic signaling and vascular cell proliferation and death. Arterioscler Thromb Vasc Biol 2002; 22: 364-373.

96. Di Virgilio F, Solini A. P2 receptors: new potential players in atherosclerosis. $\mathrm{Br} \mathrm{J}$ Pharmacol 2002; 135: 831-842.

97. Erlinge $D$, Burnstock $G$. P2 receptors in cardiovascular regulation and disease. Purinergic Signal 2008; 4: 1-20.

98. Ralevic V, Burnstock $\mathrm{G}$. Involvement of purinergic signaling in cardiovascular diseases. Drug News Perspect 2003; 16: 133-140.

99. Seye $\mathrm{Cl}$, Kong $\mathrm{Q}, \mathrm{Yu} \mathrm{N}$, Gonzalez FA, Erb L, Weisman GA. P2 receptors in atherosclerosis and postangioplasty restenosis. Purinergic Signal 2006; 2 : $471-480$

100. Horckmans M, Lantz N, Dol-Gleizes F, Savi P, Gachet C, Boeynaems JM et al. Role of $\mathrm{P}_{2} \mathrm{Y}_{4}$ nucleotide receptor in angiogenesis and inflammation. Purinergic Signal 2008; 4: S118.

101. Woodward H, Roedersheimer M, Stenmark K, Gerasimovskaya E. Extracellular ATP as a pro-angiogenic factor for systemic microvascvular endothelial cellsation. Purinergic Signal 2008; 4: S120.

102. Nilsson J, Nilsson LM, Chen YW, Molkentin JD, Erlinge D, Gomez MF. High glucose activates nuclear factor of activated T cells in native vascular smooth muscle. Arterioscler Thromb Vasc Biol 2006; 26: 794-800.

103. Brown R, Ollerstam A, Johansson B, Skott O, Gebre-Medhin S, Fredholm B et al. Abolished tubuloglomerular feedback and increased plasma renin in adenosine $A_{1}$ receptor-deficient mice. Am J Physiol Regul Integr Comp Physiol 2001; 281: R1362-R1367.

104. Gimenez-Llort L, Fernandez-Teruel A, Escorihuela RM, Fredholm BB, Tobena A, Pekny $M$ et al. Mice lacking the adenosine $A_{1}$ receptor are anxious and aggressive, but are normal learners with reduced muscle strength and survival rate. Eur J Neurosci 2002; 16: 547-550.

105. Johansson B, Halldner L, Dunwiddie TV, Masino SA, Poelchen W, Gimenez-Llort L et al. Hyperalgesia, anxiety, and decreased hypoxic neuroprotection in mice lacking the adenosine A receptor. Proc Natl Acad Sci USA 2001; 98: 9407-9412.

106. Moore KA, Nicoll RA, Schmitz D. Adenosine gates synaptic plasticity at hippocampal mossy fiber synapses. Proc Natl Acad Sci USA 2003; 100: 14397-14402.

107. Armstrong JM, Chen JF, Schwarzschild MA, Apasov S, Smith PT, Caldwell C et al. Gene dose effect reveals no Gs-coupled $A_{2 A}$ adenosine receptor reserve in murine T-lymphocytes: studies of cells from $A_{2 A}$-receptor-gene-deficient mice. Biochem $J$ 2001; 354: 123-130

108. Chen JF, Beilstein M, Xu YH, Turner TJ, Moratalla R, Standaert DG et al. Selective attenuation of psychostimulant-induced behavioral responses in mice lacking $A(2 A)$ adenosine receptors. Neuroscience 2000; 97: 195-204.

109. Chen JF, Huang Z, Ma J, Zhu J, Moratalla R, Standaert $D$ et al. $A_{2 A}$ adenosine receptor deficiency attenuates brain injury induced by transient focal ischemia in mice. $J$ Neurosci 1999; 19: 9192-9200.

110. Ledent C, Vaugeois JM, Schiffmann SN, Pedrazzini T, El Yacoubi M, Vanderhaeghen JJ et al. Aggressiveness, hypoalgesia and high blood pressure in mice lacking the adenosine $A_{2 a}$ receptor. Nature 1997; 388: 674-678.

111. Naassila M, Ledent $C$, Daoust $M$. Low ethanol sensitivity and increased ethanol consumption in mice lacking adenosine $A_{2 A}$ receptors. $J$ Neurosci 2002; 22: 10487-10493.

112. Hua X, Kovarova M, Chason KD, Nguyen M, Koller BH, Tilley SL. Enhanced mast cell activation in mice deficient in the $\mathrm{A}_{2 b}$ adenosine receptor. J Exp Med 2007; 204: 117-128

113. Ryzhov S, Zaynagetdinov R, Goldstein AE, Novitskiy SV, Dikov MM, Blackburn MR et al. Effect of $A_{2 B}$ adenosine receptor gene ablation on proinflammatory adenosine signaling in mast cells. J Immunol 2008; 180: 7212-7220.

114. Avila MY, Stone RA, Civan MM. Knockout of $A_{3}$ adenosine receptors reduces mouse intraocular pressure. Invest Ophthalmol Vis Sci 2002; 43: 3021-3026.

115. Cerniway RJ, Yang Z, Jacobson MA, Linden J, Matherne GP. Targeted deletion of $A_{3}$ adenosine receptors improves tolerance to ischemia-reperfusion injury in mouse myocardium. Am J Physiol Heart Circ Physiol 2001; 281: H1751-H1758.

116. Guo Y, Bolli R, Bao W, Wu WJ, Black Jr RG, Murphree SS et al. Targeted deletion of the $\mathrm{A}_{3}$ adenosine receptor confers resistance to myocardial ischemic injury and does not prevent early preconditioning. J Mol Cell Cardiol 2001; 33: 825-830.

117. Salvatore CA, Tilley SL, Latour AM, Fletcher DS, Koller BH, Jacobson MA. Disruption of the $A_{3}$ adenosine receptor gene in mice and its effect on stimulated inflammatory cells. $J$ Biol Chem 2000; 275: 4429-4434.

118. Tilley SL, Wagoner VA, Salvatore CA, Jacobson MA, Koller BH. Adenosine and inosine increase cutaneous vasopermeability by activating $A_{3}$ receptors on mast cells. $J$ Clin Invest 2000; 105: 361-367.

119. Zhao Z, Makaritsis K, Francis $C E$, Gavras $H$, Ravid K. A role for the $A_{3}$ adenosine receptor in determining tissue levels of CAMP and blood pressure: studies in knock-out mice. Biochim Biophys Acta 2000; 1500: 280-290.

120. Sim JA, Chaumont S, Jo J, Ulmann L, Young MT, Cho K et al. Altered hippocampa

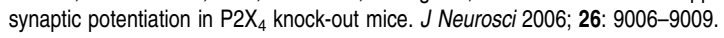


121. Inscho EW, Cook AK, Imig JD, Vial C, Evans RJ. Physiological role for $P 2 X_{1}$ receptors in renal microvascular autoregulatory behavior. J Clin Invest 2003; 112: 1895-1905.

122. Mulryan K, Gitterman DP, Lewis CJ, Vial C, Leckie BJ, Cobb AL et al. Reduced vas deferens contraction and male infertility in mice lacking $P 2 X_{1}$ receptors. Nature 2000; 403: 86-89.

123. Hechler B, Lenain N, Marchese P, Vial C, Heim V, Freund M et al. A role of the fast ATPgated $\mathrm{P}_{2} \mathrm{X}_{1}$ cation channel in thrombosis of small arteries in vivo. J Exp Med 2003; 198: 661-667.

124. Khakh BS, Gittermann D, Cockayne DA, Jones A. ATP modulation of excitatory synapses onto interneurons. J Neurosci 2003; 23: 7426-7437.

125. Finger TE, Danilova V, Barrows J, Bartel DL, Vigers AJ, Stone $L$ et al. ATP signaling is crucial for communication from taste buds to gustatory nerves. Science 2005; 310: 1495-1499.

126. Bian X, Ren J, DeVries M, Schnegelsberg B, Cockayne DA, Ford AP et al. Peristalsis is impaired in the small intestine of mice lacking the $\mathrm{P} 2 \mathrm{X}_{3}$ subunit. J Physiol 2003; 551: 309-322.

127. Cockayne DA, Hamilton SG, Zhu QM, Dunn PM, Zhong Y, Novakovic $S$ et al. Urinary bladder hyporeflexia and reduced pain-related behaviour in $\mathrm{P}_{2} \mathrm{X}_{3}$-deficient mice. Nature 2000; 407: 1011-1015.

128. Wirkner K, Sperlagh B, Illes $P$. $P 2 X_{3}$ receptor involvement in pain states. Mol Neurobiol 2007; 36: 165-183

129. Souslova V, Cesare P, Ding Y, Akopian AN, Stanfa L, Suzuki R et al. Warm-coding deficits and aberrant inflammatory pain in mice lacking $P 2 X_{3}$ receptors. Nature 2000; 407 : 1015-1017.

130. Tsuda M, Kuboyama K, Inoue T, Nagata K, Tozaki-Saitoh H, Inoue K. Behavioral phenotypes of mice lacking purinergic $\mathrm{P}_{2} \mathrm{X}_{4}$ receptors in acute and chronic pain assays. Mol Pain 2009; 5: 28.

131. Yamamoto K, Sokabe T, Matsumoto T, Yoshimura K, Shibata M, Ohura N et al. Impaired flow-dependent control of vascular tone and remodeling in $\mathrm{P}_{2} \mathrm{X}_{4}$-deficient mice. Nat Med 2006; 12: 133-137.

132. Chessell IP, Hatcher JP, Bountra C, Michel AD, Hughes JP, Green P et al. Disruption of the $\mathrm{P}_{2} \mathrm{X}_{7}$ purinoceptor gene abolishes chronic inflammatory and neuropathic pain. Pain 2005; 114: 386-396.
133. Pochet S, Garcia-Marcos M, Seil M, Otto A, Marino A, Dehaye JP. Contribution of two ionotropic purinergic receptors to ATP responses in submandibular gland ductal cells. Cell Signal 2007; 19: 2155-2164.

134. Ke HZ, Qi H, Weidema AF, Zhang Q, Panupinthu N, Crawford DT et al. Deletion of the $\mathrm{P}_{2} \mathrm{X}_{7}$ nucleotide receptor reveals its regulatory roles in bone formation and resorption. Mol Endocrinol 2003; 17: 1356-1367.

135. Lenain N, Freund M, Leon C, Cazenave JP, Gachet C. Inhibition of localized thrombosis in $\mathrm{P}_{2 \mathrm{Y}_{1}}$-deficient mice and rodents treated with MRS2179, a $\mathrm{P}_{2} \mathrm{Y}_{1}$ receptor antagonist $J$ Thromb Haemost 2003; 1: 1144-1149.

136. Cressman VL, Lazarowski E, Homolya L, Boucher RC, Koller BH, Grubb BR. Effect of loss of $\mathrm{P}_{2} \mathrm{Y}_{2}$ receptor gene expression on nucleotide regulation of murine epithelial $\mathrm{Cl}^{-}$transport. J Biol Chem 1999; 274: 26461-26468.

137. Ghanem E, Robaye B, Leal T, Leipziger J, Van Driessche W, Beauwens R et al. The role of epithelial $P 2 Y_{2}$ and $P 2 Y_{4}$ receptors in the regulation of intestinal chloride secretion. $\mathrm{Br} \mathrm{J}$ Pharmacol 2005; 146: 364-369.

138. Bar I, Guns PJ, Metallo J, Cammarata D, Wilkin F, Boeynams JM et al. Knockout mice reveal a role for ${\mathrm{P} 2 \mathrm{Y}_{6}}_{6}$ receptor in macrophages, endothelial cells, and vascular smooth muscle cells. Mol Pharmacol 2008; 74: 777-784.

139. Conley PB, Delaney SM. Scientific and therapeutic insights into the role of the platelet $\mathrm{P}_{2 \mathrm{Y}_{12}}$ receptor in thrombosis. Curr Opin Hematol 2003; 10: 333-338.

140. Greig AV, Linge C, Terenghi G, McGrouther DA, Burnstock G. Purinergic receptors are part of a functional signaling system for proliferation and differentiation of human epidermal keratinocytes. J Invest Dermatol 2003; 120: 1007-1015.

Cell Death and Disease is an open-access journal published by Nature Publishing Group. This article is licensed under a Creative Commons Attribution-Noncommercial-No Derivative Works 3.0 License. To view a copy of this license, visit http:// creativecommons.org/licenses/by-nc-nd/3.0/ 